\title{
Lumbar spinal stenosis: a brief review of the nonsurgical management
}

\section{La sténose du canal lombaire: une courte synthèse de la prise en charge non chirurgicale}

\author{
De Q. H. Tran, MD • Silvia Duong, BScPhm • \\ Roderick J. Finlayson, MD
}

Received: 15 January 2010/Accepted: 12 April 2010/Published online: 29 April 2010

(C) Canadian Anesthesiologists' Society 2010

\begin{abstract}
Purpose The purpose of this brief narrative review is to summarize the evidence derived from randomized controlled trials pertaining to the nonsurgical treatment of lumbar spinal stenosis (LSS).

Source The MEDLINE (January 1950 to the fourth week of January 2010) and EMBASE (January 1980 to 2009, week 53) databases, the MESH term "spinal stenosis", and the key words, "vertebral canal stenosis" and "neurogenic claudication", were searched. Results were limited to randomized controlled trials (RCTs) conducted on human subjects, written in English, and published in peerreviewed journals. Only RCTs pertaining to nonsurgical treatment were considered. Studies comparing conservative and surgical management or different surgical techniques were not included in the review.

Principal findings The search criteria yielded 13 RCTs. The average enrolment was 54 subjects per study. Blinded assessment and sample size justification were provided in $85 \%$ and $39 \%$ of RCTs, respectively.

The available evidence suggests that parenteral calcitonin, but not intranasal calcitonin, can transiently decrease pain in patients with LSS. In the setting of epidural blocks, local anesthetics can improve pain and function, but the benefits seem short-lived. The available evidence does not support the addition of steroids to local anesthetic agents. Based on
\end{abstract}

D. Q. H. Tran, MD $(\bowtie)$ - R. J. Finlayson, MD

Department of Anesthesia,Montreal General Hospital, McGill

University, 1650 Ave Cedar D10-144, Montreal, QC H3G 1A4,

Canada

e-mail: de_tran@hotmail.com

S. Duong, BScPhm

Faculty of Pharmacy, University of Toronto, Toronto,

ON, Canada the limited evidence, passive physical therapy seems to provide minimal benefits in LSS. The optimal regimen for active physiotherapy remains unknown. Although benefits have been reported with gabapentin, limaprost, methylcobalamin, and epidural adhesiolysis, further trials are required to validate these findings.

Conclusions Because of their variable quality, published $R C T$ s can provide only limited evidence to formulate recommendations pertaining to the nonsurgical treatment of LSS. In this narrative review, no study was excluded based on factors such as sample size justification, statistical power, blinding, definition of intervention allocation, or clinical outcomes. This aspect may represent a limitation as it may serve to overemphasize evidence derived from "weaker" trials. Further well-designed RCTs are warranted.

\footnotetext{
Résumé

Objectif L'objectif de cette courte synthèse narrative consiste à résumer les données probantes provenant des essais comparatifs randomisés se rapportant au traitement non chirurgical de la sténose du canal lombaire (SCL).

Source Les bases de données MEDLINE (de janvier 1950 à la quatrième semaine de janvier 2010) et EMBASE (de janvier 1980 à 2009, semaine 53), le terme MESH " spinal stenosis » et les mots clés « vertebral canal stenosis » et «neurogenic claudication » ont été utilisés. Les résultats ont été limités à des essais comparatifs randomisés (ECR) menés chez des sujets humains, rédigés en anglais et publiés dans des publications évaluées par les pairs. Seuls les ECR se rapportant au traitement non chirurgical ont été considérés. Les études comparant les approches conservatrice et chirurgicale ou les études comparant différentes techniques chirurgicales ont été exclues de cette synthèse.
} 
Résultats principaux Les critères de recherche ont permis d'identifier 13 ECR. Le taux de participation moyen était de 54 sujets par étude. L'évaluation en aveugle et la justification de la taille des échantillons étaient fournies dans $85 \%$ et $39 \%$ des ECR, respectivement.

Les données probantes disponibles suggèrent que la calcitonine administrée par voie parentérale, et non par voie intranasale, peut réduire de manière transitoire la douleur chez les patients atteints de SCL. Dans le cadre d'une anesthésie épidurale, les anesthésiques locaux peuvent réduire la douleur et ameliorer la capacité fonctionnelle, mais leurs bienfaits semblent être de courte durée. Les données probantes disponibles n'appuient pas l'ajout de stéroïles aux anesthésiques locaux. Il existe des données limitées en faveur d'avantages minimes de la physiothérapie passive en cas de SCL. Le programme optimal de physiothérapie active demeure inconnu. Bien que certains avantages aient été notés lors de l'utilisation de la gabapentine, du limaprost, de la méthylcobalamine et de la lyse d'adhérences épidurales, d'autres essais sont nécessaires afin de valider les résultats.

Conclusions En raison de leur qualité variable, les ECR publiées ne peuvent offrir qu'une quantité limitée de données probantes en vue de formuler des recommandations se rapportant au traitement non chirurgical d'une SCL. Dans le cadre de cette synthèse narrative, aucune étude n'a été exclue en raison de facteurs tels que la justification de la taille des échantillons, la puissance statistique, l'insu, la définition de l'attribution d'intervention ou les résultats cliniques. Cet aspect peut constituer une limite puisqu'il peut être utilisé pour amplifier l'importance des données provenant d'essais "plus faibles ». D'autres ECR bien conçus sont nécessaires.

First described more than one hundred years ago, ${ }^{1}$ lumbar spinal stenosis (LSS) is characterized by narrowing of the spinal canal with encroachment on neural structures by the surrounding soft tissues and bones. ${ }^{2}$ Although LSS can be congenital, it is more often the result of degenerative phenomena, such as spondylolisthesis and age-related changes (loss of intervertebral disc height, disc bulging, infolding of ligamentum flavum, facet joint osteoarthritis/ hypertrophy/ osteophyte/ cystic formation). ${ }^{3}$ Lumbar spinal stenosis is the most common indication for back surgery in geriatric patients. ${ }^{4-6}$ In 1994, it was estimated that one billion dollars was spent annually in the United States alone to provide surgical decompression for LSS. ${ }^{7}$ However, in elderly patients, surgery is not devoid of complications. ${ }^{4}$ Thus conservative management is often tried first, and includes physical therapy, pharmacotherapy, as well as ancillary measures, such as manipulation, bracing, traction, and electrical stimulation. ${ }^{8}$ Epidural injection of steroids can also be used for pain control. ${ }^{9}$

The last five years have seen the publication of ten review articles of variable quality pertaining to LSS. ${ }^{10-18}$ In all cases, recommendations stemmed from the combined results of non-randomized as well as randomized controlled trials (RCTs), and scrutiny of the reference lists reveals the omission of RCTs (Appendix). Furthermore, $30 \%$ of the available trials were published in the last two years (2008-2009) and, to date, they have not been incorporated in a review article. ${ }^{19-22}$ Accordingly, using a comprehensive literature search for level 1 evidence (RCTs), we decided to produce a brief and up-to-date narrative review focusing exclusively on the nonsurgical management of LSS.

\section{Search strategy and article selection criteria}

The literature search for this review was conducted during the fourth week of January 2010, using the MEDLINE (January 1950 to the fourth week of January 2010) and EMBASE (January 1980 to 2009, week 53) databases.

The MESH term, "spinal stenosis", as well as the key words, "vertebral canal stenosis" and "neurogenic claudication", were searched. Results were limited to RCTs pertaining to nonsurgical treatment conducted on human subjects, written in English, and published in peerreviewed journals. We excluded trials that investigated the impact of interventions on parameters measured in vitro (nerve root blood flow) without assessing the clinical response of patients. Randomized controlled trials published in the form of abstracts or correspondence were also discarded. Furthermore, the RCTs needed to deal exclusively with LSS. We excluded trials that enrolled patients suffering from LSS and other spine pathologies (such as radiculopathy due to disc herniation) and that indiscriminately pooled results from all subjects. However, studies providing data specific to LSS were considered in this review. For trials that included both a randomized cohort and a concurrent observational cohort of patients who declined to undergo randomization, only results pertaining to the former were kept. Studies comparing conservative and surgical management or different surgical techniques were not included in the review.

After selecting the initial articles, we examined the reference lists as well as our personal files for additional material. No RCTs were excluded based on factors such as definition of intervention allocation or primary and secondary (clinical) outcomes. However, non-randomized studies, observational case reports, and cohort studies were 
excluded to avoid potential biases introduced by institutional practices.

\section{Findings}

Our initial search criteria yielded 14 RCTs. One RCT was excluded because the authors did not conduct statistical tests to compare the results. ${ }^{23}$ Six of the remaining 13 RCTs studied pharmacological treatment (Table 1), and five investigated neuraxial blocks or epiduroscopic adhesiolysis (Table 2). Physical therapy was addressed by three studies (Table 3). As per this classification, the sum of these RCTs (14) exceeds the total found (13), because one trial compared both epidural blocks and physiotherapy to control treatment. ${ }^{22}$

Overall, the quality of the RCTs was variable. The average enrolment was 54 subjects per study. Blinded assessment and sample size justification were provided in $85 \%$ and $39 \%$ of RCTs, respectively. The duration of symptomatic LSS prior to enrolment was provided in $77 \%$ of studies and varied from 12.0 weeks to 11.4 years. Pain was the most commonly studied endpoint (69\% of trials); patient follow-up varied from 4.0 weeks to 2.5 years.

Table 1 Pharmacological treatment trials related to lumbar spinal stenosis

\begin{tabular}{|c|c|c|c|c|c|}
\hline $\begin{array}{l}\text { Authors } \\
\text { (year) }\end{array}$ & $\begin{array}{l}\text { Blinded } \\
\text { Assessment/ } \\
\text { Sample Size } \\
\text { justification }\end{array}$ & Description & $\begin{array}{l}\text { Number } \\
\text { of } \\
\text { Patients/ } \\
\text { Groups }\end{array}$ & $\begin{array}{l}\text { Primary Outcomes and Duration } \\
\text { of Follow-Up }\end{array}$ & Main Findings \\
\hline \multirow[t]{2}{*}{$\begin{array}{l}\text { Eskola } \\
\text { et al. } \\
\text { (1992) }\end{array}$} & $\mathrm{Y} / \mathrm{N}$ & $\begin{array}{l}\text { SC calcitonin (100 units) } v s \\
\text { placebo every other day for } 4 \\
\text { wks }\end{array}$ & $39 / 2$ & $\begin{array}{l}\text { Pain (VAS), walking distance, } \\
\text { jumping time until } 12 \text { wks after } \\
\text { start of treatment }\end{array}$ & $\begin{array}{l}\text { Compared with baseline, greater } \\
\text { decreases in static and dynamic } \\
\text { pain scores in calcitonin for } \\
\text { duration of } 3 \text { months }\end{array}$ \\
\hline & & $\begin{array}{l}\text { Crossover after 2-month washout } \\
\text { period }\end{array}$ & & & $\begin{array}{l}\text { No differences in walking distance } \\
\text { and jumping times }\end{array}$ \\
\hline $\begin{array}{l}\text { Podichetty } \\
\text { et al. }{ }^{26} \\
(2004)\end{array}$ & $\mathrm{Y} / \mathrm{N}$ & $\begin{array}{l}\text { Daily nasal calcitonin (400 units) } \\
\text { vs placebo for } 6 \mathrm{wks}\end{array}$ & $47 / 2$ & $\begin{array}{l}\text { Pain (VAS), walking distance, } \\
\text { walking time, physical and } \\
\text { emotional functional } \\
\text { assessment (SF-36) until } 6 \text { wks } \\
\text { after start of treatment }\end{array}$ & No differences \\
\hline $\begin{array}{l}\text { Tafazal } \\
\quad \text { et } a .^{27} \\
\quad(2007)\end{array}$ & $\mathrm{Y} / \mathrm{N}$ & $\begin{array}{l}\text { Daily nasal calcitonin (200 units) } \\
\text { vs placebo for } 3 \mathrm{wks}\end{array}$ & $37 / 2$ & $\begin{array}{l}\text { Pain (VAS), walking distance, } \\
\text { ODI, LBOS until } 4 \text { wks after } \\
\text { start of treatment }\end{array}$ & No differences \\
\hline $\begin{array}{l}\text { Yaksi } \\
\quad \text { et al. }{ }^{31} \\
\quad(2007)\end{array}$ & $\mathrm{N} / \mathrm{N}$ & $\begin{array}{l}\text { 4-month course of gabapentin } \\
\text { (starting daily dose of } 900 \mathrm{mg} \text {; } \\
\text { weekly increments of } 300 \mathrm{mg} \\
\text { until maximum of } 2,400 \mathrm{mg} \text { ) } \\
\text { combined with conservative } \\
\text { management (physical therapy, } \\
\text { corset, NSAIDs) vs } \\
\text { conservative management } \\
\text { alone }\end{array}$ & $55 / 2$ & $\begin{array}{l}\text { Pain (VAS), walking distance, } \\
\text { sensory deficits, motor deficits } \\
\text { until } 4 \text { months after start of } \\
\text { treatment }\end{array}$ & $\begin{array}{l}\text { Gabapentin: greater walking } \\
\text { distance }\left(2^{\text {nd }}, 3^{\text {rd }} \text {, and } 4^{\text {th }}\right. \\
\text { months }) \text { lower pain scores }\left(3^{\text {rd }}\right. \\
\text { and } 4^{\text {th }} \text { months), and lower } \\
\text { incidence of sensory deficits } \\
\text { ( } 4^{\text {th }} \text { month) }\end{array}$ \\
\hline $\begin{array}{l}\text { Matsudaira } \\
\quad \text { et } \text { al. }^{21} \\
(2009)\end{array}$ & $\mathrm{N} / \mathrm{N}$ & $\begin{array}{l}\text { Limaprost }(15 \mu \mathrm{g} \text { po tid }) v s \\
\text { etodolac }(400 \mathrm{mg} \text { po bid }) \text { for } 8 \\
\text { wks }\end{array}$ & $66 / 2$ & $\begin{array}{l}\text { SF-36 at } 8 \text { wks after start of } \\
\text { treatment }\end{array}$ & $\begin{array}{l}\text { Limaprost: greater improvements } \\
\text { in SF-36 subscales of physical } \\
\text { function, role physical, bodily } \\
\text { pain, vitality, and mental health } \\
\text { Limaprost: greater walking } \\
\text { distance, subjective } \\
\text { improvement, satisfaction, and } \\
\text { improvement in leg numbness }\end{array}$ \\
\hline $\begin{array}{l}\text { Waikakul } \\
\text { et al. }{ }^{35} \\
\text { (2000) }\end{array}$ & $\mathrm{Y} / \mathrm{N}$ & $\begin{array}{l}\text { 6-month course of } \\
\text { methylcobalamin }(0.5 \mathrm{mg} \text { po } \\
\text { tid) } v s \text { control }\end{array}$ & $152 / 2$ & $\begin{array}{l}\text { Pain, limitations of spinal motion, } \\
\text { walking distance, neurological } \\
\text { exam (sensorimotor functions, } \\
\text { DTR, SLR) until } 2 \text { yrs after } \\
\text { start of treatment }\end{array}$ & $\begin{array}{l}\text { Methylcobalamin: greater walking } \\
\text { distance at } 6,12 \text {, and } 18 \text { months } \\
\text { No other intergroup differences }\end{array}$ \\
\hline
\end{tabular}

bid $=$ bis in die (twice daily); DTR $=$ deep tendon reflexes; LBOS = Low Back Outcome Score; N = no; NSAIDs = non-steroidal antiinflammatory drugs; ODI = Oswestry Disability Index; $p o=$ per os; SC = subcutaneous; SF-36 = Medical Outcomes Study Short Form-36; $\mathrm{SLR}=$ straight leg raise test; $t i d=$ ter in die (three times a day); VAS $=$ visual analogue scale; $w \mathrm{k}=$ week; $\mathrm{Y}=\mathrm{yes}$ 
Table 2 Trials pertaining to epidural block and adhesiolysis for lumbar spinal stenosis

\begin{tabular}{|c|c|c|c|c|c|}
\hline $\begin{array}{l}\text { Authors } \\
\text { (year) }\end{array}$ & $\begin{array}{l}\text { Blinded } \\
\text { Assessment/ } \\
\text { Sample Size } \\
\text { justification }\end{array}$ & Description & $\begin{array}{l}\text { Number of Patients/ } \\
\text { Groups }\end{array}$ & $\begin{array}{l}\text { Primary Outcomes/ } \\
\text { Duration of Follow-Up }\end{array}$ & Main Findings \\
\hline $\begin{array}{l}\text { Fukusaki } \\
\text { et al. }{ }^{37} \\
\quad(1998)\end{array}$ & $\mathrm{Y} / \mathrm{N}$ & $\begin{array}{l}\text { Series of } 2 \text { non fluoroscopy-guided } \\
\text { epidural injections: NS vs } 1 \% \mathrm{M} \\
8 \mathrm{~mL} \text { vs } 1 \% \mathrm{M} 8 \mathrm{~mL} \text { and } \\
\text { methylprednisolone } 40 \mathrm{mg}\end{array}$ & $53 / 3$ & $\begin{array}{l}\text { Walking distance until } \\
3 \text { months after } \\
\text { treatment }\end{array}$ & $\begin{array}{l}\text { Both treatment groups: } \\
\text { greater walking } \\
\text { distance at } 1 \mathrm{wk} \\
\text { No intergroup differences } \\
\text { at } 1 \text { and } 3 \text { months } \\
\text { No differences between } 2 \\
\text { treatment groups }\end{array}$ \\
\hline $\begin{array}{l}\text { Koc et al. } \\
\quad(2009)\end{array}$ & $\mathrm{Y} / \mathrm{N}$ & $\begin{array}{l}\text { Control } v s \text { physiotherapy (2-wk } \\
\text { course) } v s \text { fluoroscopy-guided } \\
\text { interlaminal epidural }(0.5 \% \mathrm{~B} \\
15 \mathrm{mg} \text { and triamcinolone } 60 \mathrm{mg})\end{array}$ & $29 / 3$ & $\begin{array}{l}\text { Pain (VAS), walk test, } \\
\text { sit-to-stand test, } \\
\text { weight-carrying test, } \\
\text { RMDI, NHP until } \\
6 \text { months after } \\
\text { treatment }\end{array}$ & $\begin{array}{l}\text { Epidural: greater } \\
\text { improvement in VAS, } \\
\text { RMDI, and NHP than } \\
\text { control at } 2 \text { wks } \\
\text { No differences between } 2 \\
\text { treatment groups }\end{array}$ \\
\hline $\begin{array}{l}\text { Cuckler } \\
\quad \text { et al. }{ }^{45} \\
\quad(1985)\end{array}$ & $\mathrm{Y} / \mathrm{Y}$ & $\begin{array}{l}\text { Interlaminar epidural with } 1 \% \mathrm{P} \\
5 \mathrm{~mL} \text { and NS } v s \\
\text { methylprednisolone } 80 \mathrm{mg}\end{array}$ & $37 / 2$ & $\begin{array}{l}\text { Success }(75 \% \\
\text { improvement in pain } \\
\text { compared with } \\
\text { baseline) until 13- } \\
30 \text { months after } \\
\text { treatment }\end{array}$ & $\begin{array}{l}\text { No difference in short } \\
\text { term }(24 \mathrm{~h}) \text { and long } \\
\text { term }(13-30 \text { months }) \\
\text { success }\end{array}$ \\
\hline $\begin{array}{l}\text { Manchikanti } \\
\text { et al. }{ }^{19} \\
\text { (2008) }\end{array}$ & $\mathrm{Y} / \mathrm{Y}$ & $\begin{array}{l}\text { Fluoroscopy-guided caudal injection: } \\
0.5 \% \mathrm{~L} 10 \mathrm{~mL} \text { vs } 0.5 \% \mathrm{~L} 9 \mathrm{~mL} \\
\text { and betamethasone } 6 \mathrm{mg} \\
\text { (injections could be repeated based } \\
\text { on clinical response) }\end{array}$ & $\begin{array}{l}40 / 2 \text { (Preliminary } \\
\text { results of ongoing } \\
\text { trial aiming to } \\
\text { recruit total of } 120 \\
\text { patients) }\end{array}$ & $\begin{array}{l}\text { Pain (NRS) until } 1 \mathrm{yr} \\
\text { after treatment }\end{array}$ & $\begin{array}{l}\text { No intergroup differences } \\
\text { in NRS, ODI, } \\
\text { employment status, } \\
\text { opioid intake at } 3,6 \text {, } \\
\text { and } 12 \text { months }\end{array}$ \\
\hline $\begin{array}{l}\text { Manchikanti } \\
\text { et al. } \\
\text { (2009) }\end{array}$ & $\mathrm{Y} / \mathrm{Y}$ & $\begin{array}{l}\text { Fluroscopy-guided caudal (catheter } \\
\text { threaded to } \mathrm{S} 3 \text { and injected with } \\
5 \mathrm{~mL} 2 \%, 6 \mathrm{~mL} \text { NS and } 6 \mathrm{mg} \\
\text { betamethasone) vs adhesiolysis } \\
\text { (catheter threaded to level of } \\
\text { defect, adhesiolysis performed and } \\
\text { catheter injected with } 2 \% 5 \mathrm{~mL}, \\
10 \% 6 \mathrm{~mL} \text { sodium chloride } \\
\text { solution and betamethasone } 6 \mathrm{mg} \text { ) } \\
\text { (treatments could be repeated } \\
\text { based on clinical response) }\end{array}$ & $\begin{array}{l}50 / 2 \text { (Preliminary } \\
\text { results of ongoing } \\
\text { trial aiming to } \\
\text { recruit total of } 120 \\
\text { patients) }\end{array}$ & $\begin{array}{l}\text { Pain (NRS) until } 1 \mathrm{yr} \\
\text { after treatment }\end{array}$ & $\begin{array}{l}\text { Adhesiolysis: lower NRS } \\
\text { and ODI at } 3,6 \text {, and } \\
12 \text { months } \\
\text { No differences in } \\
\text { employment status and } \\
\text { opioid intake }\end{array}$ \\
\hline
\end{tabular}

$\mathrm{B}=$ bupivacaine $\mathrm{L}=$ lidocaine $\mathrm{M}=$ mepivacaine $\mathrm{N}=$ no; $\mathrm{NHP}=$ Nottingham Health Profile NRS = Numeric Rating Scale; $\mathrm{NS}=$ normal saline; ODI = Oswestry Disability Index; P = procaine; RMDI = Roland Morris Disability Index; wk = week; Y = yes; Yr = year

\section{Pharmacological therapy}

\section{Calcitonin}

Calcitonin has received considerable interest in the management of LSS because of its direct analgesic properties (through release of B-endorphin). ${ }^{24}$ Alternately, calcitonin can decrease the vascular supply to the bone by lowering its metabolic activity, thus allowing more blood to reach the compromised neural tissues. ${ }^{25}$ To date, four RCTs have investigated the use of calcitonin in LSS.

In 1992, Eskola et al. ${ }^{25}$ conducted a double-blind, crossover RCT on 39 patients suffering from LSS. The subjects initially received a subcutaneous injection of calcitonin or placebo every other day for four weeks. After a two-month washout period, the alternate solution was administered for another four weeks. When comparing with baseline levels, these authors observed that statistically greater decreases in static and dynamic pain scores were seen in the calcitonin group for up to three months irrespective of the order of administration. However, increases in walking distance and jumping time did not survive the crossover. Furthermore, at one year, none of the two groups experienced residual benefits. ${ }^{25}$ In 2004 , Podichetty et al. ${ }^{26}$ recruited 47 patients and compared a six-week regimen of intranasal calcitonin with placebo. At six weeks, no differences in pain, walking distance, walking time, and physical or emotional function were found between the 
Table 3 Trials pertaining to physical therapy for lumbar spinal stenosis

\begin{tabular}{|c|c|c|c|c|c|}
\hline $\begin{array}{l}\text { Authors } \\
\text { (year) }\end{array}$ & $\begin{array}{l}\text { Blinded } \\
\text { Assessment/ } \\
\text { Sample Size } \\
\text { justification }\end{array}$ & Description & $\begin{array}{l}\text { Number } \\
\text { of } \\
\text { Patients/ } \\
\text { Groups }\end{array}$ & $\begin{array}{l}\text { Primary Outcome and Duration } \\
\text { of Follow-Up }\end{array}$ & Main Findings \\
\hline $\begin{array}{l}\text { Koc } \\
\quad \text { et } \text { al. }^{22} \\
(2009)\end{array}$ & $\mathrm{Y} / \mathrm{N}$ & $\begin{array}{l}\text { Control } v s \text { PT (2-wk course of hot pack, } \\
\text { TENS, and US application) vs } \\
\text { fluoroscopy-guided interlaminal epidural } \\
\text { (B and triamcinolone) }\end{array}$ & $29 / 3$ & $\begin{array}{l}\text { Pain (VAS), walk test, sit-to- } \\
\text { stand test, weight-carrying } \\
\text { test, RMDI, NHP until } \\
6 \text { months after treatment }\end{array}$ & $\begin{array}{l}\text { PT: no differences } \\
\text { compared with control } \\
\text { Epidural: greater } \\
\text { improvement in VAS, } \\
\text { RMDI, and NHP than } \\
\text { in Control at } 2 \text { ws }\end{array}$ \\
\hline $\begin{array}{l}\text { Whitman } \\
\text { et al. }{ }^{46} \\
(2006)\end{array}$ & $\mathrm{Y} / \mathrm{Y}$ & $\begin{array}{l}\text { Twice weekly, 6-wk regimen: lumbar } \\
\text { flexion exercise/ walking program/ US } \\
\text { (Gp I) vs manual therapy/ exercise/ } \\
\text { walking program (Gp II) }\end{array}$ & $55 / 2$ & $\begin{array}{l}\text { GRC until } 1 \text { yr after start of } \\
\text { treatment }\end{array}$ & $\begin{array}{l}\text { Gp II: higher perceived } \\
\text { recovery }(\mathrm{GRC} \geq 3) \text { at } \\
6 \text { wks } \\
\text { No difference in } \\
\text { perceived recovery at } \\
1 \mathrm{yr} \\
\text { No differences in ODI, } \\
\text { NPRS, SSS } \\
\text { Satisfaction Subscale, } \\
\text { walking distance }\end{array}$ \\
\hline $\begin{array}{l}\text { Pua } \\
\text { et al. }{ }^{47} \\
\quad(2007)\end{array}$ & $\mathrm{Y} / \mathrm{Y}$ & $\begin{array}{l}\text { Twice weekly, 6-wk regimen: cycling } v s \\
\text { treadmill ambulation with body weight } \\
\text { support }\end{array}$ & $42 / 3$ & $\begin{array}{l}\text { ODI until } 6 \text { wks after start of } \\
\text { treatment }\end{array}$ & $\begin{array}{l}\text { No differences in ODI, } \\
\text { RMDI, VAS, perceived } \\
\text { benefit and ability to } \\
\text { walk } \geq 800 \mathrm{~m}\end{array}$ \\
\hline
\end{tabular}

$\mathrm{B}=$ bupivacaine; $\mathrm{Gp}=$ group; $\mathrm{GRC}=$ global rating of change; $\mathrm{N}=$ no; $\mathrm{NHP}=$ Nottingham Health Profile; NPRS $=$ numeric pain rating scale; ODI = Oswestry Disability Index; PT = physiotherapy; RMDI = Roland Morris Disability Index; SSS = spinal stenosis scale; TENS $=$ transcutaneous electrical nerve stimulation; US $=$ ultrasound; VAS $=$ visual analogue scale; wk $=$ week

treatment and control groups. Subsequently, in 37 subjects with LSS, Tafazal et al. ${ }^{27}$ compared a four-week regimen of intranasal calcitonin with placebo. Again, no intergroup differences were noted in terms of pain and walking distance. The Oswestry Disability Index (ODI) and Low Back Outcome Score were also similar between the two groups.

\section{Gabapentin}

Voltage-sensitive calcium and sodium channels accumulate at sites of axonal injury. ${ }^{28}$ By binding to the $\alpha_{2}$ delta subunit of these channels, gabapentin has been thought to modulate neural transmission and provide analgesia. ${ }^{29,30}$

In 2007, Yaksi et al. ${ }^{31}$ randomized 55 patients with LSS to a four-month regimen of gabapentin combined with conservative management or conservative management alone. The latter included physical therapy (lumbar flexion, pelvic traction, and strengthening of abdominal muscles), the use of a lumbosacral corset, and pharmacological treatment with non-steroidal anti-inflammatory drugs (NSAIDs). Throughout the trial, these authors observed a greater walking distance in the gabapentin group. Furthermore, pain scores were also significantly lower in the latter at the end of the third and fourth months $(3.6 \pm 2.2$ vs $4.8 \pm 2.2 ; P=0.039 ;$ and $2.9 \pm 2.6$ vs $4.7 \pm 2.2$, respectively; $P=0.006)$. After four months, a greater reduction in sensory deficits was seen with gabapentin compared with conservative management (decrease of $28.6 \%$ vs $7.4 \%$, respectively; $P=0.04) .{ }^{31}$

\section{Limaprost}

The pathogenesis of LSS may be multifactorial. Mechanical compression of the spinal cord can lead to a decrease in the vascular supply of neural tissues. ${ }^{32}$ Limaprost, an alprostadil (prostaglandin E1) analogue, possesses vasodilatory, antiplatelet, and cytoprotective properties. ${ }^{33}$

In 66 patients, Matsudaira et al. ${ }^{21}$ compared limaprost with etidolac, a NSAID. After eight weeks, subjects receiving limaprost displayed better scores pertaining to Standard Form-36 (SF-36) subscales of physical function, physical role, bodily pain, vitality, and mental health. Furthermore, greater improvements were also noted in terms of walking distance, leg numbness, and patient satisfaction. However, the two groups did not differ in terms of low back and leg pain. ${ }^{21}$

Methylcobalamin

Since high doses of vitamins, such as B6, have been used in nerve entrapment syndromes, ${ }^{34}$ Waikakul et al. ${ }^{35}$ set out to investigate the role of methylcobalamin, a methyl-vitamin 
B12, in LSS. These authors randomized 152 patients to a six-month regimen of methylcobalamin or control. All subjects also received patient education, core strengthening exercises, physiotherapy, oral analgesics, NSAIDs, muscle relaxants, and supplemental vitamins. During the entire study period (two years), there were no intergroup differences observed in terms of pain, limitations of motion, straight leg raise test, or neurological findings. However, patients receiving methylcobalamin experienced greater improvement in ambulation at six, 12 , and 18 months. ${ }^{35}$

\section{Interpretation}

The available evidence suggests that parenteral calcitonin, but not intranasal calcitonin, can lead to transient benefits ( $\leq$ three months) in patients with LSS. Although gabapentin, limaprost, and methylcobalamin have been shown to improve parameters, such as analgesia, walking distance, or sensory deficits, further trials are required to validate these findings because of the small number of RCTs involved.

\section{Epidural blockade and adhesiolysis}

\section{Epidural blockade}

In LSS, pain may be due to transient ischemia of the cauda equine. ${ }^{36}$ Thus, epidural injection of local anesthetics is commonly used to provide sympathetic blockade and vasodilation, thereby increasing blood flow to neural tissues. ${ }^{37}$ Furthermore local anesthetic agents can also exert beneficial effects by curtailing pain-induced neuronal sensitization and release of neurotransmitters involved in pain pathways. $^{38-41}$ Alternately, administration of corticosteroids in the epidural space is thought to reduce inflammatory edema of the injured nerve root, ${ }^{42}$ decrease sensitization of the dorsal horn neurons, ${ }^{43}$ and suppress the transmission of nociceptive $\mathrm{C}$ fibres. ${ }^{44}$ In clinical practice, both agents are often combined. ${ }^{37}$

To date, two RCTs have compared epidural injection of local anesthetics with placebo or conservative management (NSAIDs, physiotherapy). In 53 patients suffering from LSS, Fukusaki et al. ${ }^{37}$ performed a series of two non fluoroscopy-guided interlaminar epidural injections and randomized the injectate to saline, local anesthetic, and local anesthetic with steroid (methyprednisolone). Compared with placebo, these authors observed a greater walking distance at one week in both treatment groups (87-92 \pm 58-66 vs $23 \pm 19 \mathrm{~m} ; P<0.05)$. However, this beneficial effect did not persist, as no differences were found at one and three months. Interestingly, steroids did not add any clinical benefits. ${ }^{37}$ In 2009, Koc et al. ${ }^{22}$ randomized 29 subjects with LSS to control, physiotherapy (two-week course of hot pack, transcutaneous electrical nerve stimulation, and ultrasound application), or fluoroscopy-guided interlaminar epidural injection (bupivacaine and triamcinolone). In addition, all patients received a six-month home-based exercise program of muscle stretching/ strengthening and a two-week course of diclofenac. Intergroup analysis revealed that, compared with controls, epidural injection resulted in a greater improvement in pain intensity, Roland Morris Disability Index, and Nottingham Health Profile at two weeks. ${ }^{22}$

In addition to Fukusaki et al.'s study, ${ }^{37}$ two other RCTs have investigated the role of steroids in epidural blockade. In 1985 , Cuckler et $a .^{45}$ randomized 37 patients to an epidural injection containing procaine combined with saline or methylprednisolone. Success was defined as a $75 \%$ improvement compared with baseline. No difference in success rates was found between the two groups at the 24 hr (17.7-25.0\%) and the 13-30 month follow-ups (10.5$25 \%$ ). In 2007, Manchikanti et al. set out to recruit 120 subjects with LSS. The intended goal was to compare fluoroscopy-guided caudal injection of local anesthetic (lidocaine) with or without corticosteroid (betamethasone). In 2008, these authors published their preliminary findings in 40 patients (20 per group). Manchikanti et al. ${ }^{19}$ observed that the addition of betamethasone to lidocaine did not improve analgesia, employment status, ODI scores, and opioid intake after three, six, and twelve months.

\section{Epidural adhesiolysis}

In 2006, Manchikanti et al. set out to recruit 120 subjects with LSS. The intended goal was to compare fluoroscopyguided caudal injection of lidocaine and betamethasone with percutaneous epidural adhesiolysis. In 2009, these authors published their preliminary findings in 50 patients (25 per group). Manchikanti et al. ${ }^{20}$ observed that patients receiving adhesiolysis exhibited lower scores for pain and ODI at three, six, and twelve months. Furthermore, after adhesiolysis, the average duration of relief was also longer for patients with back pain (12.3 \pm 10.9 vs $3.2 \pm$ 3.7 weeks; $P<0.05)$ and leg pain $(12.5 \pm 11.0$ vs $3.1 \pm$ 3.8 weeks; $P<0.05)$. However, no intergroup differences in opioid intake and employment status were found.

\section{Interpretation}

Although epidural injection of local anesthetics has been shown to improve pain and function in LSS, these benefits seem short-lived ( $<$ one month). The available evidence does not support the addition of steroids to local anesthetic agents. Despite promising early results, further studies are required to validate the use of epidural adhesiolysis in LSS. 


\section{Physical therapy}

Passive physical therapy has been studied in one trial. Koc et $a .^{22}$ randomized 29 subjects with LSS to control, physiotherapy (two-week course of hot pack, transcutaneous electrical nerve stimulation, and ultrasound application), or epidural injection (bupivacaine and triamcinolone). In addition, all patients received a six-month home-based exercise program of muscle stretching and strengthening as well as a two-week course of diclofenac. No difference was found between the physiotherapy and control groups. In contrast, as previously stated, compared with controls, epidural injection resulted in a greater improvement in pain intensity, Roland Morris Disability Index, and Nottingham Health Profile at two weeks. ${ }^{22}$

To date, two RCTs have attempted to determine the optimal regimen for (active) physical therapy. In 2006, Whitman et al. ${ }^{46}$ randomized 55 patients with LSS to two six-week physiotherapy regimens. The first group (Group I) received lumbar flexion exercises, a progressive treadmill ambulation program, and subtherapeutic pulsed ultrasound. The second group (Group II) received manual physical therapy (spine, pelvis, and lower extremities), exercises (designed to improve mobility, strength and coordination), and a body weight-supported treadmill ambulation program. In addition, all subjects received a home exercise program, and they were asked to take a daily walk. Whitman et $a l^{46}$ defined perceived recovery as a global rating of change score $\geq 3$. At six weeks, Group II presented a higher rate of perceived recovery (79 vs $41 \%$ of patients; $P=0.0015)$. However, no statistical differences were found at one year and on long-term telephone follow-up (27.4-29.0 months). Furthermore, throughout the study period, the authors reported no intergroup differences in terms of pain, walking distance, ODI, and Spinal Stenosis Scale Satisfaction Subscale scores. ${ }^{46}$ In 2007, Pua et al. ${ }^{47}$ randomized 42 patients to a six-week physiotherapy regimen of cycling or treadmill ambulation with body weight support. All subjects also received a home exercise program of flexion/ neural mobilization exercises. At three and six weeks, no differences were found in terms of disability (ODI, Roland Morris Disability Index) and pain. ${ }^{47}$

\section{Interpretation}

The limited evidence available suggests that passive physical therapy provides minimal benefits. The optimal regimen for active physiotherapy remains unknown. Although the combination of manual therapy/ exercise/ body weight-supported ambulation results in a higher rate of perceived recovery than the combination of flexion exercise/ progressive treadmill ambulation/ ultrasound, these benefits did not persist beyond six weeks and did not translate into an improvement of objective indices. Furthermore, no differences were found between cycling and treadmill ambulation with body weight support.

\section{Discussion}

In terms of pharmacological treatment, the available evidence suggests that parenteral calcitonin, but not intranasal calcitonin, can transiently decrease pain in patients with LSS. Although benefits have been reported with gabapentin, limaprost, and methylcobalamin, further trials are required to validate these findings. In the setting of epidural blocks, local anesthetic agents can improve pain and function, but the benefits seem short-lived. The available evidence does not support the addition of steroids to local anesthetics. Despite promising results, further studies are required to validate the use of epidural adhesiolysis for patients with LSS. Based on the limited evidence available, passive physical therapy seems to provide minimal benefits in LSS. The optimal regimen for active physiotherapy remains unknown.

A critical survey of the available RCTs can provide an effective tool to establish focused recommendations pertaining to the nonsurgical treatment of LSS. For instance, in this review, no evidence was found to support the use of epidural steroid injection (ESI). This is stark contrast with recently published review articles. Using the pooled results of case series, observational trials and RCTs, $70 \%$ of the latter recommended ESI. Furthermore, despite the unclear benefits and limited efficacy associated with active and passive physiotherapy, respectively, $90 \%$ of recent reviews advocated the use of physiotherapy. Alarmingly, a device that can be potentially harmful (through muscle deconditioning), such as a stabilization brace, was recommended for occasional use by $40 \%$ of reviews despite the absence of RCTs (Appendix). Since our review article incorporated RCTs missing from previous publications, new and promising therapeutic modalities (limaprost, methylcobalamin, and epidural adhesiolysis) have also been identified. Although the limited evidence available does not permit their clinical implementation at this time, further investigation is certainly warranted.

For practical reasons, a decision was taken to limit this review to RCTs published in the English language. Although such a restriction may constitute a methodological limitation, we believe that its impact on the paper's conclusions is small, since expansion of our search criteria (using the same databases and time periods) to languages 
Table 4 Nonsurgical management strategies warranting further clinical investigation

\begin{tabular}{ll}
\hline Pharmacotherapy & - Efficacy of acetaminophen, NSAIDs, selective COX 2 inhibitors, and opioids \\
& - Confirmatory trials for gabapentin, methylcobalamin, and limaprost \\
& - Pregabalin $v s$ gabapentin \\
& - Optimal regimen for active physical therapy \\
Physical therapy & - Palpation- $v s$ fluoroscopy-guided interlaminal epidural injection of LA \\
Interventional Treatment & - Fluoroscopy-guided interlaminar $v s$ transforaminal $v s$ caudal epidural injection of LA \\
& - Confirmatory trials for epiduroscopic adhesiolysis \\
Multimodal Treatment & - Efficacy of multimodal treatment \\
& - Best combination for multimodal management
\end{tabular}

COX = cyclooxygenase; LA = local anesthetic agent; NSAID = non-steroidal anti-inflammatory drug

other than English yielded only three additional RCTs. ${ }^{48-50}$ No attempt was made in this review to produce a metaanalysis. In our view, given the wide array of modalities used for pharmacological and physical therapy, patient enrolment would have been insufficient to support a systematic pooling of data. For interventional treatments, the heterogeneity in techniques (palpation- vs fluoroscopyguided epidural block vs adhesiolysis) would have constituted an obstacle. In this narrative review, no RCT was excluded based on factors such as sample size justification, statistical power, blinding, definition of intervention allocation, or clinical outcomes. This may represent a limitation to our article, as it may serve to overemphasize evidence derived from "weaker" RCTs. Most importantly, if trials lacked sample size justification, provided limited enrolment, and found no difference between study groups, we cannot exclude the possibility that they were inadequately powered to answer the question they sought to investigate.
Despite current best evidence, many issues regarding nonsurgical modalities remain unresolved and, thus, require elucidation through well-designed and meticulously conducted RCTs (Table 4). Future trials should use sample size justification and blinded assessment. Furthermore, the duration of LSS prior to enrolment and the length of follow-up should be rigorously controlled. For trials investigating interventional treatment, evidence-based standardized conservative management should be implemented in the control group. Lastly, most studies have focused thus far on single or dual therapeutic modalitiesthe role of multimodal therapy warrants investigation.

\section{Appendix}

See Table 5

Table 5 Recently published reviews of lumbar spinal stenosis

\begin{tabular}{|c|c|c|c|c|c|}
\hline $\begin{array}{l}\text { Authors } \\
\text { (reference } \\
\text { number) } \\
\text { (year) }\end{array}$ & $\begin{array}{l}\text { Focused } \\
\text { on } \\
\text { Treatment }\end{array}$ & $\begin{array}{l}\text { Restricted } \\
\text { to RCTs }\end{array}$ & $\begin{array}{l}\text { Inclusion of All } \\
\text { Contemporary RCTs* } \\
\text { Pertaining to Nonsurgical } \\
\text { Treatment }\end{array}$ & $\begin{array}{l}\text { Contemporary RCTs Pertaining } \\
\text { to Nonsurgical Treatment Not } \\
\text { Included in Review (reference } \\
\text { numbers) }\end{array}$ & Recommended Nonsurgical Treatment \\
\hline $\begin{array}{c}\text { Katz et al. } \\
\quad(2008)\end{array}$ & $\mathrm{N}$ & $\mathrm{N}$ & $\mathrm{N}$ & $25,26,27,31,35,46,47$ & $\begin{array}{l}\text { Stabilization brace (occasional), } \\
\text { PT (core-strengthening exercises), } \\
\text { pharmacotherapy (acetaminophen, } \\
\text { NSAIS, mild opioid), ESI }\end{array}$ \\
\hline $\begin{array}{l}\text { Kim } \\
\quad \text { et al. }{ }^{10} \\
\quad(2005)\end{array}$ & $\mathrm{N}$ & $\mathrm{N}$ & $\mathrm{N}$ & $25,26,35,37,45$ & $\begin{array}{l}\text { Rest, restricted movement, stabilization } \\
\text { brace (occasional), PT (massage, heat, } \\
\text { cold, US, TENS, core-strengthening } \\
\text { exercises), acupuncture, exercises (bike, } \\
\text { treadmill, aquatic ambulation), balance } \\
\text { training, patient education, biofeedback, } \\
\text { relaxation training, pharmacotherapy } \\
\text { (acetaminophen, aspirin, NSAID, } \\
\text { tramadol, opioid, muscle relaxant, } \\
\text { antidepressant, anticonvulsant), ESI }\end{array}$ \\
\hline
\end{tabular}


Table 5 continued

\begin{tabular}{|c|c|c|c|c|c|}
\hline $\begin{array}{l}\text { Authors } \\
\text { (reference } \\
\text { number) } \\
\text { (year) }\end{array}$ & $\begin{array}{l}\text { Focused } \\
\text { on } \\
\text { Treatment }\end{array}$ & $\begin{array}{l}\text { Restricted } \\
\text { to RCTs }\end{array}$ & $\begin{array}{l}\text { Inclusion of All } \\
\text { Contemporary RCTs* } \\
\text { Pertaining to Nonsurgical } \\
\text { Treatment }\end{array}$ & $\begin{array}{l}\text { Contemporary RCTs Pertaining } \\
\text { to Nonsurgical Treatment Not } \\
\text { Included in Review (reference } \\
\text { numbers) }\end{array}$ & Recommended Nonsurgical Treatment \\
\hline $\begin{array}{l}\text { Yuan } \\
\text { et al. }{ }^{11} \\
\quad(2005)\end{array}$ & $\mathrm{Y}$ & $\mathrm{N}$ & $\mathrm{N}$ & $26,35,37$ & $\begin{array}{l}\text { Rest, PT (flexion-based exercises), aquatic } \\
\text { training, exercise, patient education } \\
\text { (posture, ADL), pharmacotherapy } \\
\text { (aspirin, NSAID, muscle relaxant, } \\
\text { antidepressant, oral corticosteroid, } \\
\text { calcitonin), ESI }\end{array}$ \\
\hline $\begin{array}{l}\text { Atlas } \\
\quad \text { et al. } \\
\quad(2006)\end{array}$ & $\mathrm{Y}$ & $\mathrm{N}$ & $\mathrm{N}$ & $25,35,37,45$ & PT, exercise, patient education, analgesics \\
\hline $\begin{array}{l}\text { Babb } \\
\text { et al. } .^{13} \\
\quad(2006)\end{array}$ & $\mathrm{N}$ & $\mathrm{N}$ & $\mathrm{N}$ & $25,26,35,37,45$ & $\begin{array}{l}\text { Stabilization brace (occasional), PT, weight } \\
\text { loss program (if overweight), exercises } \\
\text { (bicycle, aquatic therapy, inclined } \\
\text { treadmill), pharmacotherapy (NSAID, } \\
\text { oral steroid), ESI }\end{array}$ \\
\hline $\begin{array}{l}\text { Englund }^{14} \\
\quad(2007)\end{array}$ & $\mathrm{N}$ & $\mathrm{N}$ & $\mathrm{N}$ & $25,35,37,46$ & $\begin{array}{l}\text { PT (core-strengthening exercises), exercises } \\
\text { (bicycle, aquatic therapy, inclined } \\
\text { treadmill), pharmacotherapy } \\
\text { (acetaminophen, NSAID, anticonvulsant, } \\
\text { oral corticosteroid) }\end{array}$ \\
\hline $\begin{array}{l}\text { Chad }^{15} \\
\quad(2007)\end{array}$ & $\mathrm{N}$ & $\mathrm{N}$ & $\mathrm{N}$ & $25,26,35,37,45,46$ & $\begin{array}{l}\text { Stabilization brace (occasional), PT (back/ } \\
\text { leg lengthening exercises, US, TENS), } \\
\text { weight loss program (if overweight), } \\
\text { exercises (bicycle, walking), } \\
\text { pharmacotherapy (NSAID, muscle } \\
\text { relaxant), ESI }\end{array}$ \\
\hline $\begin{array}{l}\text { Markman } \\
\text { et al. } .^{16} \\
\quad(2008)\end{array}$ & $\mathrm{N}$ & $\mathrm{N}$ & $\mathrm{N}$ & $25,27,31,35,37,45,46,47$ & No clear recommendation \\
\hline $\begin{array}{l}\text { Rahman } \\
\quad \text { et al. }{ }^{17} \\
\quad(2008)\end{array}$ & $\mathrm{N}$ & $\mathrm{N}$ & $\mathrm{N}$ & $25,27,31,35,37,45,46,47$ & $\begin{array}{l}\text { PT (back/ leg lengthening exercises, } \\
\text { mobility training, US, TENS), } \\
\text { pharmacotherapy (NSAID, muscle } \\
\text { relaxant), ESI }\end{array}$ \\
\hline $\begin{array}{l}\text { Aliabadi } \\
\text { et al. } .^{18} \\
\quad(2009)\end{array}$ & $\mathrm{N}$ & $\mathrm{N}$ & $\mathrm{N}$ & $19,25,26,27,31,35,45,47$ & $\begin{array}{l}\text { PT (manual PT, body weight-supported } \\
\text { treadmill). } \\
\text { No clear recommendation pertaining to ESI }\end{array}$ \\
\hline
\end{tabular}

$\mathrm{ADL}=$ activities of daily living; $\mathrm{ESI}=$ epidural steroid injection; $\mathrm{N}=$ no; NSAID $=$ non-steroidal anti-inflammatory drug; PT $=$ physiotherapy; RCT $=$ randomized controlled trial; TENS $=$ transcutaneous electrical nerve stimulation; US $=$ ultrasound; $\mathrm{Y}=$ yes

* A contemporary RCT is defined as a RCT published no later than the year prior to the publication of the review article

\section{References}

1. Sachs B, Frankel V. Progressive and kyphotic rigidity of the spine. J Nerv Ment Dis 1900; 27: 1.

2. Katz JN, Harris MB. Clinical practice. Lumbar spinal stenosis. N Engl J Med 2008; 358: 818-25.

3. Arnoldi CC, Brodsky AE, Cauchoix J, et al. Lumbar spinal stenosis and nerve root entrapment syndromes. Definition and classification. Clin Orthop Relat Res 1976; 115: 4-5.

4. Deyo RA, Ciol MA, Cherkin DC, Loeser JD, Bigos SJ. Lumbar spinal fusion. A cohort study of complications, reoperations, and resource use in the Medicare population. Spine (Phila Pa 1976) 1993; 18: 1463-70

5. Deyo RA, Gray DT, Kreuler W, Mirza S, Martin BI. United States trends in lumbar fusion surgery for degenerative conditions. Spine (Phila Pa 1976) 2005; 30: 1441-5
6. Ciol MA, Deyo RA, Howell E, Kreif S. An assessment of surgery for spinal stenosis: time trends, geographic variations, complications, and reoperations. J Am Geriatr Soc 1996; 44: 285-90.

7. Taylor VM, Deyo RA, Cherkin DC, Kreuter W. Low back pain hospitalization. Recent United States trends and regional variations. Spine (Phila Pa 1976) 1994; 19: 1207-13

8. Watters WC $3^{\text {rd }}$, Baisden J, Gilbert TJ, et al. Degenerative lumbar spinal stenosis: an evidence-based clinical guideline for the diagnosis and treatment of degenerative lumbar spinal stenosis. Spine J 2008; 8: 305-10.

9. Friedly $J$, Chan L, Deyo $R$. Increases in lumbosacral injections in the Medicare population. Spine (Phila Pa 1976) 2007; 32: 1754-60

10. Kim SL, Lim RD. Spinal stenosis. Dis Mon 2005; 51: 6-17.

11. Yuan PS, Booth RE Jr, Albert TJ. Nonsurgical and surgical management of lumbar spinal stenosis. Instr Course Lect 2005; 54: 303-12. 
12. Atlas SJ, Delitto A. Spinal stenosis: surgical versus nonsurgical treatment. Clin Orthop Relat Res 2006; 443: 198-207.

13. Babb A, Carlson WO. Spinal stenosis. S D Med 2006; 59: 103-5.

14. Englund J. Lumbar spinal stenosis. Curr Sports Med Rep 2007; 6: 50-5.

15. Chad DA. Lumbar spinal stenosis. Neurol Clin 2007; 25: 407-18.

16. Markman JD, Gaud KG. Lumbar spinal stenosis in older adults: current understanding and future directions. Clin Geriatr Med 2008; 24: 369-88.

17. Rahman RK, Nowak DD, Gelb DE, Poelstra KA, Ludwig SC. Lumbar spinal stenosis. Current Orthopaedic Practice 2008; 19: 351-6.

18. Aliabadi $H$, Isaacs $R$. Lumbar spinal stenosis: a brief review. Neurosurgery Quarterly 2009; 19: 200-6.

19. Manchikanti L, Cash KA, McManus CD, Pampati V, Abdi S. Preliminary results of a randomized, equivalence trial of fluoroscopic caudal epidural injections in managing chronic low back pain: Part 4-Spinal stenosis. Pain Physician 2008; 11: 833-48.

20. Manchikanti L, Cash KA, McManus CD, Pampati V, Singh V, Benyamin $R$. The preliminary results of a comparative effectiveness evaluation of adhesiolysis and caudal epidural injections in managing chronic low back pain secondary to spinal stenosis: a randomized, equivalence controlled trial. Pain Physician 2009; 12: E341-54.

21. Matsudaira K, Seichi A, Kunogi J, et al. The efficacy of prostaglandin E1 derivative in patients with lumbar spinal stenosis. Spine (Phila Pa 1976) 2009; 34: 115-20

22. Koc Z, Ozcakir S, Sivrioglu K, Gurbet A, Kurcukoglu S. Effectiveness of physical therapy and epidural steroid injections in lumbar spinal stenosis. Spine (Phila Pa 1976) 2009; 34: 985-9

23. Porter $R W$, Miller $C G$. Neurogenic claudication and root claudication treated with calcitonin. A double-blind trial. Spine (Phila Pa 1976) 1988; 13: 1061-4

24. Fraioli F, Fabri A, Gnessi L, Moretti C, Santoro C, Felici M. Subarachnoid injection of salmon calcitonin induces analgesia in man. Eur J Pharmacol 1982; 78: 381-2.

25. Eskola A, Pohjolainen T, Alaranta H, Soini J, Tallroth K, Slatis $P$. Calcitonin treatment in lumbar spinal stenosis: a randomized, placebo-controlled, double-blind, cross-over study with one-year follow-up. Calcif Tissue Int 1992; 50: 400-3.

26. Podichetty VK, Segal AM, Lieber M, Mazanec DJ. Effectiveness of salmon calcitonin nasal spray in the treatment of lumbar canal stenosis: a double-blind, randomized, placebo-controlled, parallel group trial. Spine (Phila Pa 1976) 2004; 29: 2343-9

27. Tafazal SI, Ng L, Sell P. Randomised placebo-controlled trial on the effectiveness of nasal salmon calcitonin in the treatment of lumbar spinal stenosis. Eur Spine J 2007; 16: 207-12.

28. Moll C, Mourre C, Lazdunski M, Ulrich J. Increase of sodium channels in demyelinated lesions of multiple sclerosis. Brain Res 1991; 556: 311-6.

29. Cheng JK, Chiou LC. Mechanisms of the antinociceptive action of gabapentin. J Pharmacol Sci 2006; 100: 471-86.

30. Serpell MG, Neuropathic Pain Study Group. Gabapentin in neuropathic pain syndromes: a randomised, double blind, placebo-controlled trial. Pain 2002; 99: 557-66.

31. Yaksi A, Ozgonenel L, Ozgonenel B. The efficiency of gabapentin therapy in patients with lumbar spinal stenosis. Spine 2007; 32 : 939-42

32. Delamarter RB, Bohlman HH, Dodge LD, Biro C. Experimental lumbar spinal stenosis. Analysis of the cortical evoked potentials, microvasculature and histopathology. J Bone Joint Surg Am 1990; 72: 110-20.

33. Swainston Harrison T, Plosker GL. Limaprost. Drugs 2007; 67: 109-18.

34. Keniston RC, Nathan PA, Leklem JE, Lockwood RS. Vitamin B6, vitamin C, and carpal tunnel syndrome. A cross-sectional study of 441 adults. J Occup Environ Med 1997; 39: 949-59.

35. Waikakul W, Waikakul S. Methylcobalamin as an adjuvant medication in conservative treatment of lumbar spinal stenosis. J Med Assoc Thai 2000; 83: 825-31.

36. Tsuji H, Tamaki T, Itoh T, et al. Redundant nerve roots in patients with degenerative lumbar spinal stenosis. Spine (Phila Pa 1976) 1985; 10: 72-82

37. Fukusaki M, Kobayashi I, Hara T, Sumikawa K. Symptoms of spinal stenosis do not improve after epidural steroid injection. Clin J Pain 1998; 14: 148-51.

38. Katz WA, Rothenberg $R$. The nature of pain: pathophysiology. J Clin Rheumatol 2005; 11(2 Suppl): S11-5.

39. Melzack R, Coderre TJ, Katz J, Vaccarino AL. Central neuroplasticity and pathological pain. Ann N Y Acad Sci 2001; 933: 157-74.

40. Pasqualucci A, Varrassi G, Braschi A, et al. Epidural local anesthetic plus corticosteroid for the treatment of cervical brachial radicular pain: single injection versus continuous infusion. Clin J Pain 2007; 23: 551-7.

41. Decosterd I, Woolf CJ. Spared nerve injury: an animal model of persistent peripheral neuropathic pain. Pain 2000; 87: 149-58.

42. Winnie AP, Hartman JT, Myers HL Jr, Ramamurthy S, Baragan $V$. Pain clinic. II. Intradural and extradural corticosteroids for sciatica. Anesth Analg 1972; 51: 990-1003.

43. Coderre TJ. Contribution of protein kinase $\mathrm{C}$ to central sensitization and persistent pain following tissue injury. Neurosci Lett 1992; 140: 181-4.

44. Johansson A, Hao J, Sjolund B. Local corticosteroid application blocks transmission in normal nociceptive C-fibres. Acta Anaesthesiol Scand 1990; 34: 335-8.

45. Cuckler JM, Bernini PA, Wiesel SW, Booth RE Jr, Rothman RH, Pickens GT. The use of epidural steroids in the treatment of lumbar radicular pain. A prospective, randomized, double-blind study. J Bone Joint Surg Am 1985; 67: 63-6.

46. Whitman JM, Flynn TW, Childs JD, Wainner RS, Gill HE, Ryder $M G$, et al. A comparison between two physical therapy treatment programs for patients with lumbar spinal stenosis: a randomized clinical trial. Spine (Phila Pa 1976) 2006; 31: 2541-9

47. Pua YH, Cai CC, $\operatorname{Lim} K C$. Treadmill walking with body weight support is no more effective than cycling when added to an exercise program for lumbar spinal stenosis: a randomized controlled trial. Aust J Physiother 2007; 53: 83-9.

48. Kurihara A, Tanabe T, Mishima Y. Therapeutic effect of OP-1206 $\alpha$-CD on lumbar spinal canal stenosis: multi-center comparative double blind clinical study (Japanese). Rinsho Iyaku 1996; 12: 511-29.

49. Uratsuji M, Kurihara A, Iguchi T. The optimal dose for OP-1206 $\alpha$-CD on lumbar spinal canal stenosis: multi-center comparative double blind clinical study (Japanese). Rinsho Iyaku 1996; 12: 489-509.

50. Cheng $P, M a C$, Wang XL, Lang HT. Salmon calcitonin plus rehabilitive therapy for lumbar spinal stenosis (Chinese). Chin J Clin Rehabil 2006; 10: 32-4. 